\title{
GAMBARAN KUALITAS KEHIDUPAN REMAJA (STUDI PADA REMAJA DI DAERAH GEMPA BUMI)
}

\author{
Fransisca I. R. Dewi ${ }^{1 *}$, Rita Markus Idulfilastri ${ }^{2}$, Lisa Angela ${ }^{3}$, Meylisa Permata Sari ${ }^{4}$ \\ ${ }^{1}$ Fakultas Psikologi, Universitas Tarumanagara Jakarta \\ Email:fransiscar@fpsi.untar.ac.id \\ ${ }^{2}$ Fakultas Psikologi, Universitas Tarumanagara Jakarta \\ Email: ritamarkus@fpsi.untar.ac.id \\ ${ }^{3}$ Fakultas Psikologi, Universitas Tarumanagara Jakarta \\ Email:lisa.705160211@stu.untar.ac.id \\ ${ }^{4}$ Fakultas Psikologi, Universitas Tarumanagara Jakarta \\ Email:meylisa.sari@fpsi.untar.ac.id
}

\begin{abstract}
Indonesia's territory which is located at the confluence of three major tectonic plates in the world, causes Indonesia to experience frequent natural disasters such as earthquakes. Three areas in Indonesia that experienced major earthquakes in the last 10 years are Aceh, Mataram / Lombok, and Palu. The earthquake not only caused material damage but also psychological trauma. Post-disaster trauma is vulnerable to children and adolescents. Problems experienced from a disaster have an impact on various aspects of life so that they can affect the quality of life of the victim. Quality of life is very important especially for adolescents, because adolescents who have higher quality of life tend to have low physical and psychological problems. Therefore, this study aims to describe the quality of life of adolescents in earthquake areas. Participants in this study were 437 senior high school students aged 12-19 years. All participants came from Aceh (NAD), Mataram (NTB), and Palu (Central Sulawesi). Data collection was carried out through a survey with WHOQOL-BREF questionnaire which consisted of 4 aspects, namely physical, psychological, social, and environmental. Data analysis used descriptive statistical techniques which is processed using the IBM 22.0 version of the SPSS (Statistical Product and Service Solutions) computer program and the LISREL 8.80 program. Data collection was carried out before the COVID-19 Pandemic occurred. The results showed that the quality of life of adolescents in terms of physical, psychological, social, and environmental aspects in Aceh, Mataram and Palu was classified as moderate. The results of this study can be used as a first step in designing interventions related to the quality of life of adolescents in earthquake areas.
\end{abstract}

Keywords: quality of life, adolescent, natural disasters, earthquake

\begin{abstract}
ABSTRAK
Posisi wilayah Indonesia yang terletak pada pertemuan tiga lempeng tektonik utama di dunia menyebabkan Indonesia sering mengalami bencana alam seperti gempa bumi. Daerah di Indonesia yang mengalami gempa besar dalam 10 tahun terakhir yaitu Aceh, Mataram/Lombok, dan Palu. Gempa tersebut tidak hanya memberikan dampak berupa kerusakan materiil tetapi juga trauma psikologis. Trauma pasca bencana ini rentan dialami oleh anak-anak dan remaja. Masalah yang dialami dari satu peristiwa bencana berdampak pada berbagai aspek kehidupan sehingga dapat memengaruhi kualitas hidup korban. Kualitas hidup sangat penting khususnya bagi remaja karena remaja yang memiliki kualitas kehidupan yang tinggi cenderung rendah mengalami permasalahan fisik dan psikologis. Oleh sebab itu, penelitian ini bertujuan untuk mengetahui gambaran kualitas hidup remaja di daerah gempa. Partisipan dalam penelitian ini adalah 437 siswa SMA sederajat berusia 12-19 tahun. Partisipan berasal dari Aceh (NAD), Mataram (NTB), dan Palu (Sulawesi Tengah). Pengumpulan data menggunakan metode survei melalui kuesioner WHOQOLBREF yang terdiri dari 4 aspek yaitu fisik, psikologis, sosial dan lingkungan. Analisis data menggunakan teknik statistik deskriptif dengan bantuan komputer program SPSS (Statistical Product and Service Solutions) versi IBM 22.0. Pengambilan data dilaksanakan sebelum terjadinya pandemi Covid-19. Hasil penelitian menunjukkan bahwa kualitas hidup remaja ditinjau dari aspek fisik, psikologis, sosial, dan lingkungan di Aceh, Mataram, dan Palu tergolong sedang. Hasil penelitian ini dapat digunakan sebagai langkah awal dalam merancang intervensi terkait kualitas kehidupan remaja di daerah gempa.
\end{abstract}

Kata Kunci: kualitas kehidupan, remaja, bencana alam, gempa bumi 


\section{PENDAHULUAN}

\section{Latar Belakang}

Indonesia merupakan negara yang rawan terjadinya bencana alam seperti gempa bumi dan gunung meletus. Hal ini karena Indonesia terletak pada pertemuan tiga lempeng tektonik aktif yaitu lempeng Pasifik, lempeng Eurasia dan lempeng Hindia-Australia. Ancaman bahaya gempa bumi tersebar di hampir seluruh wilayah kepulauan Indonesia, baik dalam skala kecil hingga skala besar yang merusak. Wilayah yang rawan bencana gempa bumi di Indonesia tersebar mulai dari Aceh, Sumatera Utara, Sumatera Barat, Bengkulu, Lampung, Jawa Barat, Daerah Istimewa Yogyakarta, Jawa Tengah, Jawa Timur, Bali, Nusa Tenggara, Pulau Sulawesi, Kepulauan Maluku, Maluku Utara dan wilayah Papua. Mengingat sifat bencana tersebut yang tidak dapat diprediksi waktu terjadinya, didukung tingginya tingkat persebaran bencana dan tingginya tingkat repetisi bencana, maka diperlukan perhatian ekstra dalam mengatasi atau mempersiapkan proses penanganan pada saat bencana maupun pasca bencana.

Berdasarkan data dari Kepala Badan Meteorologi, Klimatologi, dan Geofisika (BMKG) (Hastuti, 2020) mengatakan bahwa setelah tahun 2017 gempa bumi di Indonesia semakin meningkat. Jika dalam setahun biasanya sekitar 4000-6000 kali dengan sekitar 200 gempa yang kekuatannya lebih dari 5 SR. Setelah tahun 2017, gempa bumi meningkat menjadi lebih dari 7000 kali dalam setahun. Pada tahun 2018 bahkan semakin meningkat menjadi 11.920 kali gempa.

Daerah Palu, Lombok, dan Aceh merupakan wilayah terjadinya gempa besar di Indonesia selama 10 tahun terakhir. Badan Nasional Penanggulangan Bencana (BNPB) (Hadi, 2018) mencatat sebanyak 2.113 jumlah korban meninggal akibat gempa dan tsunami Palu, Sulawesi Tengah dan sekitarnya yang terjadi pada tanggal 28 September 2018. Korban tersebar di beberapa lokasi yaitu Palu korban tewas tercatat 1.703 orang, Donggala 171 orang, Sigi 223 orang, Parigi Moutong 15 orang, dan Pasangkayu 1 orang. Sementara, korban yang mengalami luka-luka mencapai 4.612 orang. Di tahun yang sama tepatnya 29 Juli 2018 gempa terjadi di Lombok dengan korban meninggal dilaporkan sebanyak 560 orang serta hampir 400 ribu orang mengungsi (BNPB, 2018). Setahun kemudian, 21 Juni 2019, Lombok kembali diguncang gempa. Sementara di awal tahun 2021, daerah Aceh telah mengalami 21 kali gempa bumi dengan kekuatan mencapai 5 SR (Fadil, 2021).

Bencana adalah ancaman terhadap kesejahteraan populasi yang menghambat kemajuan sosial ekonomi membebani jaring pengaman sosial dan membutuhkan bantuan dan intervensi pemulihan (Frankenberg et al., 2008). Mulai dari tempat tinggal hancur sehingga harus mengungsi, kehilangan anggota keluarga atau mengalami kekerasan selama di pengungsian dapat menimbulkan traumatis. Trauma yang sering terjadi adalah PTSD atau post-traumatic stress disorder. Secara umum PTSD memiliki argumen bahwa rasa stress atau tekanan yang dialami oleh seseorang ketika pernah mengalami kejadian dimasa lalunya yang mengancam hidup atau menyebabkan penderitaan yang sangat besar. Setelah kejadian gempa bumi yang traumatis yang dirasakan oleh korban antara lain kecemasan yang intens bahwa hal itu akan terulang, munculnya kembali bayangan-bayangan visual akan kejadian, kewaspadaan berlebih, dan reaksi mudah terkejut hingga kesulitan tidur. Masyarakat menjadi lebih peka dan mudah tersinggung karena berbagai rasa tak berdaya ataupun perasaan tidak dimengerti oleh orang lain. Jika trauma ini tidak segera ditangani dapat menimbulkan gangguan jiwa.

Menurut Vijayakumar et al. (2006) anak-anak dan remaja lebih peka serta menerima dampak paling berat pada situasi traumatis. Mereka merasakan ketidakberdayaan dan pasivitas, kurangnya responsivitas seperti biasa, ketakutan secara umum, gairah dan kebingungan yang meningkat. 
Dampak buruk tersebut salah satunya timbul dari pengalaman tinggal di tenda pengungsian tanpa adanya akses ke sekolah dan tempat untuk bermain. Selain itu banyaknya kasus kekerasan terhadap anak-anak dan juga wanita merupakan masalah yang cukup berat di dalam konteks pengungsian (Pellupessy et al., 2011). Peek (2008) mengatakan bahwa anak dan remaja lebih rentan mengalami ketidakstabilan di berbagai isu perilaku, psikologis dan emosi. Dampak psikologis yang dirasakan dapat berbentuk PTSD, depresi, kecemasan, tekanan emosional, dan gangguan tidur. Penanganan yang tepat dibutuhkan untuk mengatasi dampak tersebut.

Literatur menunjukkan bahwa beberapa gejala kecemasan berhubungan dengan buruknya kualitas kehidupan pada keluarga inti, lingkungan sekitar, kompetensi atau kecakapan seseorang, hubungan sosial, penampilan fisik, kesejahteraan mental, dan rasa sakit. Secara nyatanya, kecemasan yang tinggi berhubungan dengan tingkat depresi yang tinggi pula (Matos et al., 2003; Moksnes \& Espnes, 2012), dan penilaian terhadap diri sendiri yang rendah (Moksnes \& Espnes, 2012); sementara itu depresi berhubungan dengan rasa bahagia yang rendah (Cheng \& Furnham, 2003; Uusitalo-Malmivaara \& Lehto, 2013), kepuasan hidup yang rendah (Lambert et al., 2014) dan penilaian terhadap diri sendiri yang rendah (Cheng \& Furnham, 2003). Tantangan terberat yang dihadapi remaja adalah krisis identitas berupa kebingungan mengetahui siapa dirinya dan kelak menjadi seperti apa (Testa, 1996).

Selain itu, permasalahan yang muncul ketika terjadinya bencana dapat memengaruhi berbagai aspek dalam kehidupan korban. Misalnya dari aspek kesehatan, korban perlu mengonsumsi obatobatan medis untuk menyembuhkan luka akibat gempa atau kurangnya istirahat karena situasi kondisi yang masih kacau pasca gempa. Kemudian, memengaruhi aspek psikologis seperti muncul rasa takut, kehilangan, kesedihan, depresi. Hubungan sosial dengan sesama juga dipengaruhi oleh peristiwa bencana seperti tidak mendapatkan dukungan sosial khususnya dari keluarga karena keluarga juga menjadi korban. Selanjutnya, memengaruhi aspek lingkungan seperti tidak memiliki rumah, sulitnya mendapatkan akses air bersih selama di tenda pengungsian, serta minimnya kesempatan untuk berekreasi. Keempat aspek ini yaitu fisik, psikologis, sosial dan lingkungan merupakan faktor penentu kualitas kehidupan seseorang (World Health Organization [WHO], 2009). Dengan kata lain, peristiwa bencana dapat memengaruhi kualitas hidup korban.

Kesejahteraan telah dipelajari secara luas sebagai indikator penting dari kualitas hidup (Helliwell et al., 2015). Istilah kualitas hidup dan lebih khususnya kualitas hidup yang sehat menunjukkan pada kondisi fisik, psikologis, dan masalah sosial terlihat seperti area yang berbeda yang dipengaruhi oleh pengalaman pribadi seseorang, keyakinan, harapan. Persepsi dua orang dengan status kesehatan yang sama dapat memiliki kualitas hidup yang berbeda.

Menurut WHO (2009) kualitas hidup adalah persepsi individu terhadap posisi mereka dalam kehidupan pada konteks budaya dan sistem nilai dimana mereka tinggal, dalam hubungan dengan tujuan hidup, harapan, standar, dan fokus hidup mereka. Hal ini merupakan konsep tingkatan yang terangkum secara kompleks mencakup kesehatan fisik, kesejahteraan psikologis, tingkat kebebasan, hubungan sosial dan hubungan kepada karakteristik lingkungan. Pengukuran kualitas kehidupan menurut WHO terdiri dari kesehatan fisik, kesejahteraan psikologis, tingkat kemandirian, hubungan sosial, hubungan dengan lingkungan, dan keadaan spiritual. Keenam aspek ini dipersempit menjadi 4 aspek saja dalam versi singkatnya (WHOQOL-BREF) yaitu aspek fisik, psikologis, sosial, dan lingkungan. 
Kualitas hidup menjadi pertimbangan penting untuk mengevaluasi persepsi individu dalam menjalankan kehidupannya. Menurut Kreitler dan Arush (2004) kualitas hidup sebagai persepsi individu mengenai keberfungsiannya di dalam menjalani kehidupan. Dengan kata lain, penilaian individu terhadap keberadaannya di dalam kehidupan, dalam konteks budaya dan sistem nilai yang dianutnya. Bronfenbrenner (1979) memusatkan perhatian pada interaksi antara anak dengan lingkungan. Interaksi ini dianalisa dalam beberapa tingkat hirarki. Pada tingkat yang paling rendah (sistem mikro) interaksi antara anak dengan lingkungan keluarga, sekolah, tetangga. Di tingkat selanjutnya, mesosistem, dua atau lebih mikrosistem berinteraksi. Contoh analisis interaksi anak di sekolah dibandingkan dengan interaksi anak didalam keluarga mencerminkan mesosistem tertentu. Pada tingkat selanjutnya adalah eksosistem yang berarti pula lingkungan makro. Eksosistem berisi dimana anak tidak terlibat secara langsung. Bagaimanapun juga setting mempengaruhi interaksi mereka dengan lingkungan. Contoh eksosistem adalah tempat kerja ayah, afiliasi orangtua dengan tetangga, pelayanan pegawai negeri. Mikrosistem, mesosistem, dan eksosistem menetapkan perkembangan anak. Untuk mengetahui kesejahteraan anak-anak, peneliti dalam kualitas hidup mutlak menggunakan ketiga sistem tersebut dan mempelajari pengaruh mereka secara interaktif dan berkesinambungan (Sirgy, 2012).

Michalos (2014) mengatakan bahwa terdapat empat karakteristik atribut konsep kualitas hidup, yaitu pernyataan rasa puas individu terhadap kehidupan secara umum; kapasitas mental individu untuk mengevaluasi kehidupannya sendiri; suatu status fisik, mental, sosial dan emosi yang ditentukan oleh individu sendiri berdasarkan referensinya, pengkajian sendiri bahwa kondisi hidupnya adekuat dan terbebas dari ancaman.Gilman dan Huebner (dalam Kumcagiz \& Sahin, 2017) mengatakan bahwa kualitas hidup pada remaja sangat penting karena remaja yang memiliki kualitas hidup yang tinggi cenderung mengalami masalah fisik dan psikologis yang lebih rendah jika dibandingkan dengan remaja yang memiliki kualitas hidup yang rendah.

Oleh sebab itu, penting untuk mengetahui kualitas kehidupan remaja di daerah gempa. Harapannya ketika mengetahui gambaran kualitas kehidupan remaja, nantinya dapat dirancang suatu intervensi yang sesuai untuk meningkatkan kualitas kehidupan remaja di daerah gempa. Maka dari itu, penelitian ini bertujuan untuk mendapatkan gambaran mengenai kualitas kehidupan remaja dari segi aspek fisik, psikologis, sosial dan lingkungan di daerah gempa yaitu Aceh, Mataram (Lombok) dan Palu.

\section{Rumusan Masalah}

Rumusan masalah dalam penelitian ini adalah bagaimana gambaran kualitas hidup aspek fisik, psikologis, sosial, dan lingkungan remaja yang tinggal di daerah gempa?

\section{METODE PENELITIAN Partisipan dan prosedur penelitian}

Partisipan dalam penelitian ini adalah 437 siswa SMA sederajat berusia 12-19 tahun. Seluruh partisipan berasal dari Aceh (NAD), Palu (Sulawesi Tengah) dan Mataram (NTB). Penelitian ini diawali dengan menghubungi pihak sekolah untuk memohon perizinan melakukan penelitian. Kemudian, jika sudah mendapatkan izin peneliti menyebarkan kuesioner dan pulpen kepada siswa/i di kelas. Selanjutnya peneliti menjelaskan mengenai tata cara pengisian serta lembar informed consent. Jika siswa/i telah memahami instruksi maka mereka dapat mengerjakan dengan waktu 45 menit. Setelah itu, kuesioner dikumpulkan dan peneliti memberikan souvenir sebagai bentuk apresiasi kepada partisipan yang telah bersedia mengikuti penelitian ini. Data yang telah dikumpulkan dianalisis menggunakan bantuan komputer program SPSS (Statistical Product and Service Solutions) versi IBM 22.0. Teknik analisis data yang digunakan dalam penelitian ini adalah 
dengan statistik deskriptif. Statistik deskriptif adalah metode statistik yang digunakan untuk menganalisis data yang digunakan untuk mendapatkan gambaran secara keseluruhan mengenai variabel penelitian yang diteliti pada suatu sampel tertentu (Gravetter \& Forzano, 2018).

\section{Pengukuran}

Pengukuran kualitas kehidupan menggunakan kuesioner dari WHOQOL-BREF yang terdiri dari 4 aspek yaitu aspek fisik, psikologis, sosial dan lingkungan dengan total 26 pertanyaan. Kuesioner ini menggunakan skala likert dengan rentang skala 1 sampai dengan skala 4. Setiap pernyataan memiliki (4) empat pilihan alternatif pilihan respons yang menunjukan derajat kesesuaian dengan diri subjek yaitu Sangat Setuju (SS), Setuju (S), Tidak Setuju (TS), Sangat Tidak Setuju (STS).

\section{HASIL DAN PEMBAHASAN}

Berikut adalah demografi partisipan dalam penelitian ini.

Tabel 1. Demografi Partisipan Penelitian

\begin{tabular}{|c|c|c|c|c|c|c|}
\hline \multirow[t]{2}{*}{ Karakteristik } & \multicolumn{2}{|c|}{$\begin{array}{c}\text { Aceh } \\
(\mathrm{N}=168)\end{array}$} & \multicolumn{2}{|c|}{$\begin{array}{c}\text { Mataram } \\
(\mathrm{N}=70)\end{array}$} & \multicolumn{2}{|c|}{$\begin{array}{c}\text { Palu } \\
(\mathrm{N}=199)\end{array}$} \\
\hline & $\mathbf{N}$ & $\%$ & $\mathbf{N}$ & $\%$ & $\mathbf{N}$ & $\%$ \\
\hline \multicolumn{7}{|l|}{ Usia } \\
\hline $14-15$ & 15 & 8.90 & 17 & 24.30 & 45 & 22.6 \\
\hline $16-17$ & 143 & 85.10 & 53 & 75.70 & 111 & 55.8 \\
\hline $18-19$ & 10 & 6.00 & 0 & 0 & 43 & 21.6 \\
\hline \multicolumn{7}{|l|}{ Jenis Kelamin } \\
\hline Laki-laki & 87 & 51.80 & 33 & 47.10 & 53 & 26.6 \\
\hline Perempuan & 81 & 48.20 & 37 & 52.90 & 146 & 73.4 \\
\hline \multicolumn{7}{|l|}{ Kelas } \\
\hline $\mathrm{X}$ & 12 & 7.10 & 35 & 50.00 & 78 & 39.2 \\
\hline XI & 7 & 4.20 & 35 & 50.00 & 12 & 6.0 \\
\hline XII & 149 & 88.70 & 0 & 0 & 109 & 54.8 \\
\hline \multicolumn{7}{|l|}{ Agama } \\
\hline \multirow{6}{*}{$\begin{array}{l}\text { Muslim } \\
\text { Protestan } \\
\text { Katholik } \\
\text { Buddha } \\
\text { Hindu } \\
\text { N/A }\end{array}$} & 167 & 99.40 & 57 & 81.40 & 186 & 93.5 \\
\hline & 0 & 0 & 1 & 1.40 & 10 & 5 \\
\hline & 0 & 0 & 1 & 1.40 & 0 & 0 \\
\hline & 0 & 0 & 1 & 1.40 & 0 & 0 \\
\hline & 0 & 0 & 9 & 12.90 & 3 & 1.5 \\
\hline & 1 & 0.60 & 1 & 1.40 & 0 & 0 \\
\hline
\end{tabular}

Tabel 1 menunjukkan bahwa mayoritas dalam penelitian ini adalah siswa/I berusia 16-17 tahun. Kemudian, jumlah siswa perempuan (264 siswi) lebih banyak daripada siswa laki-laki (173 siswa). Jika dilihat dari kelasnya, maka mayoritas partisipan berada di kelas XII (258 siswa/i), diikuti oleh kelas X (125 siswa/i) dan kelas XI (54 siswa/i). Mayoritas partisipan beragama Muslim.

Gambaran kualitas hidup aspek fisik, psikologis, sosial dan lingkungan siswa/i yang tinggal di Aceh, Mataram dan Palu.

\section{Kualitas hidup aspek fisik (QoL Physical)}

Aspek ini berkaitan dengan kualitas hidup dari segi fisik seperti bagaimana pandangan individu mengenai kondisi energi dan kelelahan, rasa sakit dan tidak nyaman, serta kualitas tidur dan istirahat pada dirinya (WHO, 2009). Berikut adalah data mengenai kualitas hidup aspek fisik partisipan di Aceh, Mataram, dan Palu. 
Tabel 2. Kualitas Hidup Aspek Fisik

\begin{tabular}{|c|c|c|c|c|c|c|c|c|}
\hline \multirow{2}{*}{ Daerah } & \multicolumn{4}{|c|}{ Rendah } & \multicolumn{2}{|c|}{ Sedang } & \multicolumn{2}{|c|}{ Tinggi } \\
\hline & $M$ & $S D$ & $\mathbf{N}$ & $\%$ & $\mathbf{N}$ & $\%$ & $\mathbf{N}$ & $\%$ \\
\hline Aceh & 14.52 & 1.94 & 35 & 20.83 & 101 & 60.12 & 32 & 19.05 \\
\hline Mataram & 13.88 & 1.87 & 11 & 15.70 & 47 & 67.15 & 12 & 17.15 \\
\hline Palu & 14.36 & 1.98 & 30 & 15.1 & 131 & 65.8 & 38 & 19.1 \\
\hline
\end{tabular}

Berdasarkan data partisipan sebanyak 437, ditemukan bahwa 35 siswa Aceh, 11 siswa Mataram dan 30 siswa Palu memiliki QoL Physical yang tergolong rendah artinya kualitas hidup dari segi fisik kurang baik seperti cepat merasa lelah, merasa tidak nyaman, dan kurang istirahat. Mayoritas siswa memiliki QoL Physical yang tergolong sedang (101 siswa Aceh, 47 siswa Mataram, 131 siswa Palu) berarti secara umum siswa cukup berenergi, memiliki kualitas tidur yang baik dan cenderung sehat. Kemudian, terdapat 32 siswa Aceh, 12 siswa Mataram dan 38 siswa Palu yang memiliki QoL Physical yang tergolong tinggi artinya memiliki kualitas hidup fisik yang sangat baik seperti tidak mudah kelelahan, fisik yang sehat serta memiliki tidur dan istirahat yang berkualitas. Hasil penelitian ini sejalan dengan penelitian yang dilakukan Michalos. Michalos (2014) mengatakan bahwa terdapat empat karakteristik atribut konsep kualitas hidup, yaitu pernyataan rasa puas individu terhadap kehidupan secara umum; kapasitas mental individu untuk mengevaluasi kehidupannya sendiri; suatu status fisik, mental, sosial dan emosi yang ditentukan oleh individu sendiri.

\section{Kualitas hidup aspek psikologis (QoL Psychological)}

Aspek ini berkaitan dengan kualitas hidup dari segi psikologis seperti bagaimana pandangan individu mengenai citra dan penampilan tubuh, perasaan negatif, perasaan positif, harga diri, serta berpikir, belajar, memori dan konsentrasi (WHO, 2009). Berikut adalah data mengenai kualitas hidup aspek psikologis partisipan di Aceh, Mataram dan Palu.

Tabel 3. Kualitas Hidup Aspek Psikologis

\begin{tabular}{lccccccccc}
\hline \multirow{2}{*}{ Daerah } & \multicolumn{4}{c}{} & \multicolumn{2}{c}{ Rendah } & \multicolumn{2}{c}{ Sedang } & \multicolumn{2}{c}{ Tinggi } \\
\cline { 2 - 10 } & $\boldsymbol{M}$ & $\boldsymbol{S D}$ & $\mathbf{N}$ & $\mathbf{\%}$ & $\mathbf{N}$ & $\mathbf{\%}$ & $\mathbf{N}$ & \% \\
\hline Aceh & 14.65 & 2.25 & 25 & 14.88 & 120 & 71.43 & 23 & 13.69 \\
Mataram & 13.99 & 2.18 & 11 & 15.70 & 47 & 67.15 & 12 & 17.15 \\
Palu & 13.97 & 2.47 & 34 & 17.1 & 141 & 70.9 & 24 & 12.1 \\
\hline
\end{tabular}

Dari total 437 partisipan ditemukan bahwa 25 siswa Aceh, 11 siswa Mataram dan 34 siswa Palu memiliki QoL Psychological yang tergolong rendah artinya kualitas psikologis siswa kurang baik. Siswa cenderung memiliki pandangan negatif terhadap penampilan tubuhnya, merasa tidak berharga atau sulit untuk konsentrasi atau mengingat pelajaran. Mayoritas siswa memiliki QoL Psychological yang tergolong sedang (120 siswa Aceh, 47 siswa Mataram, 141 siswa Palu) berarti secara umum siswa memiliki pandangan yang cukup baik terhadap citra dan penampilan tubuh, merasa berharga, serta dapat berpikir, belajar, memori dan konsentrasi dengan cukup baik. Kemudian, terdapat 23 siswa Aceh, 12 siswa Mataram, dan 24 siswa Palu yang memiliki QoL Psychological yang tergolong tinggi artinya kualitas psikologis siswa sangat baik. Mereka memiliki pandangan yang sangat baik terhadap citra dan penampilan tubuhnya, merasa berharga, serta dapat berpikir, belajar, memori dan konsentrasi dengan sangat baik. Hal ini sejalan dengan pendapat Matos et al. (2003) serta Moksnes dan Espnes (2012), yang menunjukkan bahwa beberapa gejala kecemasan berhubungan dengan buruknya kualitas kehidupan pada keluarga inti, lingkungan sekitar, kompetensi atau kecakapan seseorang, hubungan sosial, penampilan fisik, 
kesejahteraan mental, dan rasa sakit. Secara nyatanya, kecemasan yang tinggi berhubungan dengan tingkat depresi yang tinggi pula.

\section{Kualitas hidup aspek sosial (QoL Social)}

Aspek ini berkaitan dengan kualitas hidup dari segi sosial seperti bagaimana pandangan individu mengenai hubungan pribadi, dukungan sosial dan pertemanan atau relasi dengan lawan jenis (WHO, 2009). Berikut adalah data mengenai kualitas hidup aspek sosial partisipan di Aceh, Mataram dan Palu.

Tabel 4. Kualitas Hidup Aspek Sosial

\begin{tabular}{|c|c|c|c|c|c|c|c|c|}
\hline \multirow{2}{*}{ Daerah } & \multicolumn{4}{|c|}{ Rendah } & \multicolumn{2}{|c|}{ Sedang } & \multicolumn{2}{|c|}{ Tinggi } \\
\hline & $M$ & $S D$ & $\mathbf{N}$ & $\%$ & $\mathbf{N}$ & $\%$ & $\mathbf{N}$ & $\%$ \\
\hline Aceh & 14.01 & 2.89 & 21 & 12.50 & 117 & 69.64 & 30 & 17.86 \\
\hline Mataram & 13.85 & 3.20 & 9 & 12.86 & 48 & 68.57 & 13 & 18.57 \\
\hline Palu & 13.97 & 2.98 & 39 & 19.6 & 123 & 61.8 & 37 & 18.6 \\
\hline
\end{tabular}

Dari total 437partisipan ditemukan bahwa 21 siswa Aceh, 9 siswa Mataram, dan 39 siswa Palu memiliki QoL Social yang tergolong rendah artinya kualitas hidup khususnya aspek sosial kurang baik seperti kurangnya dukungan sosial yang didapatkan siswa. Mayoritas siswa memiliki QoL Social yang tergolong sedang (117 siswa Aceh, 48 siswa Mataram, 123 siswa Palu) berarti secara umum siswa memiliki hubungan pribadi yang cukup baik, mendapatkan dukungan sosial serta pertemanan atau relasi dengan lawan jenis yang cukup baik. Kemudian, terdapat 30 siswa Aceh, 13 siswa Mataram, dan 37 siswa Palu yang memiliki QoL Social yang tergolong tinggi artinya kualitas hidup aspek sosial siswa sangat baik. Mereka memiliki hubungan pribadi yang sangat baik, sangat mendapatkan dukungan sosial dari sekitarnya dan juga memiliki pertemanan atau relasi dengan lawan jenis yang sangat baik.

Cedera akibat bencana menimbulkan keterbatasan fisik yang tidak dapat dihindari sehingga seseorang membutuhkan perawatan khusus agar dapat menjalani kehidupan sehari-hari (Kementrian Kesehatan RI, 2014). Individu yang berkebutuhan khusus harus tetap memiliki rasa percaya diri yang tinggi, tetap ikut berperan aktif di dalam lingkungan masyarakat, tidak merasa malu dengan keadaan dirinya dan merasa puas atas keadaan dirinya walaupun dirinya tidak sempurna seperti yang lain.Perasaan kepuasan kehidupan seseorang secara umum inilah yang menurut Meeberg (dalam Galloway, 2005) diartikan sebagai kualitas hidup. Ada bermacammacam faktor yang dapat mempengaruhi kualitas hidup. Menurut Sun, $\mathrm{Wu}, \mathrm{Qu}, \mathrm{Lu}$ dan Wang (2013) selain karakteristik sosiodemografi, stress dan kemampuan koping, dukungan sosial juga dapat mempengaruhi kualitas hidup individu. Individu dengan pengalaman dukungan sosial yang cukup, tidak akan terlalu stres saat mereka menghadapi masalah, mengatasinya lebih baik, dan pengalaman dalam hal positif akan ditanggapi lebih positif (Taylor, 2015). Pernyataan Meeberg dan Taylor tersebut sejalan dengan hasil penelitian ini.

Penelitian yang dilakukan Luszczynska et al. (2013), sebagai studi meta-analisis dengan cara menganalisis 14 penelitian mengenai hubungan antara dukungan sosial dengan kualitas hidup diantara pasien kanker paru-paru menemukan bahwa secara keseluruhan terdapat hubungan antara dukungan sosial dan kualitas hidup yang tergantung pada jenis dan sumber dukungannya. Temuan Luszczynska et al. sejalan dengan penelitian ini. 
Penelitian lain yang sejalan dengan penelitian ini yaitu penelitian Dewianti dan Kuswardhani (2013), tentang fungsi keluarga, dukungan sosial dan kualitas hidup lansia di wilayah kerja Puskesmas III Denpasar Selatan. Hasil uji chi square dari penelitian ini menunjukkan bahwa fungsi keluarga dan dukungan sosial berhubungan secara bermakna dengan kualitas hidup, di mana fungsi keluarga serta dukungan sosial yang baik meningkatkan kualitas hidup.

\section{Kualitas hidup aspek lingkungan (QoL Environment)}

Aspek ini berkaitan dengan kualitas hidup dari segi lingkungan seperti bagaimana pandangan individu mengenai (1) sumber pendapatannya (keuangan); (2) kebebasan, keselamatan dan keamanan fisik; (3) kualitas dan aksesibilitas perawatan kesehatan dan sosial; (4) lingkungan rumah; (5) peluang untuk memperoleh informasi dan keterampilan baru; (6) partisipasi dan peluang untuk memiliki waktu luang dan rekreasi; (7) lingkungan fisik seperti polusi, kebisingan, lalu lintas, iklim; (8) serta transportasi (WHO, 2009). Berikut adalah data mengenai kualitas hidup aspek lingkungan partisipan di Aceh, Mataram dan Palu.

Tabel 5. Kualitas Hidup Aspek Lingkungan

\begin{tabular}{lccccccccc}
\multicolumn{1}{c}{ Daerah } & \multicolumn{4}{c}{ Rendah } & \multicolumn{2}{c}{ Sedang } & \multicolumn{2}{c}{ Tinggi } \\
\cline { 2 - 10 } & $\boldsymbol{M}$ & $\boldsymbol{S D}$ & $\mathbf{N}$ & $\mathbf{\%}$ & $\mathbf{N}$ & $\mathbf{\%}$ & $\mathbf{N}$ & \% \\
\hline Aceh & 12.38 & 2.12 & 28 & 16.67 & 109 & 64.88 & 31 & 18.45 \\
Mataram & 13.56 & 2.04 & 12 & 17.14 & 48 & 68.57 & 10 & 14.29 \\
Palu & 13.42 & 2.08 & 50 & 25.1 & 125 & 62.8 & 24 & 12.1 \\
\hline
\end{tabular}

Dari total 437 partisipan ditemukan bahwa 28 siswa Aceh, 12 siswa Mataram dan 50 siswa Palu memiliki QoL Environment yang tergolong rendah artinya kualitas lingkungan siswa kurang baik. Siswa mungkin kurang mendapatkan peluang untuk memperoleh informasi dan keterampilan baru atau merasa tidak aman dengan lingkungannya. Mayoritas siswa memiliki QoL Environment yang tergolong sedang (109 siswa Aceh, 48 siswa Mataram, 125 siswa Palu) berarti secara umum cukup memiliki kualitas lingkungan yang baik seperti terhindar dari kebisingan dan cukup mudah mendapatkan transportasi untuk berkegiatan sehari-hari. Kemudian, terdapat 31 siswa Aceh, 10 siswa Mataram dan 24 siswa Palu yang memiliki QoL Environment yang tergolong tinggi artinya kualitas lingkungan siswa sangat baik. Mereka mendapatkan kebebasan, keselamatan dan keamanan fisik, memiliki kesempatan untuk berekreasi atau sangat mudah mendapatkan akses kesehatan maupun sosial yang berkualitas.

Hasil penelitian ini selaras dengan penelitian yang telah dilakukan Bronfenbrenner (1979) yang memusatkan perhatian pada interaksi antara anak dengan lingkungan. Interaksi ini dianalisa dalam beberapa tingkat hirarki yaitu mikrosistem, mesosistem, dan eksosistem. Ketiga tingkat hirarki tersebut menetapkan perkembangan anak. Peneliti dalam kualitas hidup mutlak menggunakan ketiga sistem tersebut dan mempelajari pengaruh mereka secara interaktif dan berkesinambungan untuk mengetahui kesejahteraan anak (Sirgy, 2012).

\section{KESIMPULAN DAN SARAN}

Berdasarkan hasil penelitian di atas, maka dapat disimpulkan bahwa remaja di daerah Aceh, Mataram dan Palu memiliki kualitas hidup tergolong sedang. Dari segi aspek fisik, siswa/i cukup berenergi, memiliki kualitas tidur yang baik dan cenderung sehat. Dari segi aspek psikologis, siswa/i memiliki pandangan yang cukup baik terhadap citra dan penampilan tubuh, merasa berharga, serta dapat berpikir, belajar, memori dan konsentrasi dengan cukup baik. Dari segi aspek sosial, siswa/i memiliki hubungan pribadi yang cukup baik, mendapatkan dukungan sosial serta pertemanan atau relasi dengan lawan jenis yang cukup baik. Kemudian, dari segi aspek 
lingkungan, siswa/i cukup memiliki kualitas lingkungan yang baik seperti terhindar dari kebisingan dan cukup mudah mendapatkan transportasi untuk berkegiatan sehari-hari.

Saran yang dapat diberikan peneliti untuk penelitian selanjutnya adalah peneliti dapat mengaitkan kualitas hidup dengan variabel lain sehingga dapat merancang suatu intervensi untuk meningkatkan kualitas hidup remaja. Kemudian, bagi pihak sekolah dapat mengadakan bimbingan psikologis kepada siswa/i dalam rangka menjaga atau meningkatkan kualitas hidup mereka. Sementara, pemerintah juga dapat berpartisipasi dengan melakukan sosialisasi serta mengajarkan kepada masyarakat khususnya remaja mengenai kemampuan menghadapi bencana seperti jenisjenis bencana, tempat berlindung, apa yang harus segera dilakukan dan tidak boleh dilakukan ketika bencana terjadi.

\section{Ucapan Terima Kasih (Acknowledgement)}

Terima kasih kami ucapkan kepada LPPM Universitas Tarumanagara yang telah mendanai penelitian ini sehingga dapat terlaksana dengan baik. Rasa terima kasih dan apresiasi juga kami ucapkan kepada kepala sekolah, guru, serta siswa/i SMA sederajat di daerah Aceh, Mataram dan Palu yang telah memberikan dukungan, serta pihak-pihak yang berkontribusi dalam penyelesaian penelitian ini.

\section{REFERENSI}

Badan Nasional Penanggulangan Bencana. (2018). Info bencana edisi agustus 2018. BNPB. https://bnpb.go.id/uploads/24/info-bencana-agustus-2018-1.pdf

Bronfenbrenner, U. (1979). The ecology of human development experiments by nature and design. Harvard University Press.

Cheng, H., \& Furnham, A. (2003). Personality, self-esteem, and demographic predictions of happiness and depression, Personality and Individual Differences, 34(6), 921-942. https://doi.org/10.1016/S0191-8869(02)00078-8.

Dewianti, A. T., \& Kuswardhani, T. (2013). Fungsi keluarga, dukungan sosial, dan kualitas hidup lansia di wilayah kerja puskesmas iii denpasar selatan. Public Health and Preventive Medicine Archive, 1(2), 134-138. https://doi.org/10.15562/phpma.v1i2.176

Fadil, I. (2021, January 8). Sejak 1 januari, 21 kali gempa bumi guncang sumut dan aceh. Merdeka. https://www.merdeka.com/peristiwa/sejak-1-januari-21-kali-gempa-bumi-guncangsumut-dan-aceh.html

Frankenberg, E., Friedman, J., Gillespie, T., Ingwersen, N., Pynoos, R., Rifai, I., Sikoki, B., Steinberg, A., Sumantri, C., Suriastini, W., \& Thomas, D. (2008). Mental health in sumatra after the tsunami. American Journal of Public Health, 98, 1671-7. https://doi.org/10.2105/AJPH.2007.120915.

Galloway, S., Bell, D., Hamilton, C., \& Scullion, A. (2005). Well-being and quality of life: Measuring the benefit of culture and sport: Literature review and thinkpiece. Edinburgh: Analytical Services Division, Scottish Executive Education Department.

Gravetter, F.J., \& Forzano, L-A. B. (2018). Research methods for the behavioral sciences (6th ed.). Cengage.

Hadi, S. (2018, October 21). Jumlah korban tewas terkini gempa dan tsunami palu 2.113 orang. Tempo. https://nasional.tempo.co/read/1138400/jumlah-korban-tewas-terkini-gempa-dantsunami-palu-2-113-orang/full\&view $=$ ok

Hastuti, R. K. (2020, October 6). Hampir 12.000 pertahun, kejadian gempa bumi di RI melonjak. CNBC Indonesia. https://www.cnbcindonesia.com/news/20201006202037-4192368/hampir-12000-pertahun-kejadian-gempa-bumi-diri-melonjak 
Helliwell, J. F., Layard, R., \& Sachs, J. (Eds). (2015). World happiness report 2015. Sustainable Development Solutions Network.

Kementrian Kesehatan RI. (2014). Situasi Penyandang Disabilitas. Departemen Kesehatan.

Kreitler, S., \& Arush, M. W. B. (Eds.). (2004). Psychosocial aspects of pediatric oncology. John Wiley \& Sons.

Kumcagiz, H.\& Şahin, C. (2017). The relationship between quality of life and social support among adolescents. SHS Web of Conferences, 37(3), 1-7. https://doi.org/10.1051/shsconf/20173701053.

Lambert, A. J., Eadeh, F. R., Peak, S. A., Scherer, L. D., Schott, J. P., \& Slochower, J. M. (2014). Toward a greater understanding of the emotional dynamics of the mortality salience manipulation: Revisiting the "affect-free" claim of terror management research. Journal of Personality and Social Psychology, 106(5), 655-678. https://doi.org/10.1037/a0036353

Luszczynska, A., Pawlowska, I., Cieslak, R., Knoll, N., \& Scholz, U. (2013). Social support and quality of life among lung cancer patients: A systematic review. Psycho-Oncology, 22, 2160-2168. https://doi.org/10.1002/pon.3218

Matos, M. G., Barrett, P., Dadds, M. (2003). Anxiety, depression, and peer relationships during adolescence: Results from the portuguese national health behaviour in school-aged children survey. Eur J Psychol Educ, 18, 3-14. https://doi.org/10.1007/BF03173600

Michalos, A. C. (Ed.). (2014). Encyclopedia of quality of life and well-being research. Springer Science+Business Media Dordrecht.

Moksnes, U., \& Espnes, G. (2012). Self-esteem and emotional health in adolescents - gender and age as potential moderators. Scandinavian Journal of Psychology, 53, 483-9. https://doi.org/10.1111/sjop.12021

Peek, L. (2008). Children and disasters: Understanding vulnerability, developing capacities, and promoting resilience - an introduction. Children Youth and Environments, 18(1), 1-29.

Pelupessy, D., Bretherton, D., \& Ride, A. (2011). Indonesia. Dalam Ride, A. \& Bretherton, D., Community Resilience in Natural Disaster. Palgrave Macmillan.

Sirgy, M. J. (2012). The psychology of quality of life: hedonic wellbeing, life satisfaction, and eudaimonia (2nd ed.). Springer.

Sun, W., Wu, M., Qu, P., Lu, C., \& Wang, L. (2013). Quality of life of people living with hiv/aids under the new epidemic characteristics in china and the associated factors. PLOS ONE, 8(5), 1-10. https://doi.org/10.1371/journal.pone.0064562

Taylor, S.E. (2015). Health psychology ( $9^{\text {th }}$ ed.). McGraw Hill.

Testa, M.A., \& Simonson, D.C. (1996). Assessment of quality-of-life outcomes. New England Journal of Medicine, 334, 835-840. http://dx.doi.org/10.1056/NEJM199603283341306

Uusitalo-Malmivaara, L., \& Lehto, J. E. (2013). Social factors explaining children's subjective happiness and depressive symptoms. Soc Indic Res, 111,603-615. https://doi.org/10.1007/s11205-012-0022-z

Vijayakumar, L., Thara R., John, S., \& Chelleppa, S. (2006). Psychological interventions after tsunami in tamil nadu, india. International Review of Psychiatry, 18(3), 225-231. https://doi.org/10.1080/09540260600655912

World Health Organization. (2009). The world health organization's WHOQOL-BREF quality of life assesment: Psychometric properties and results of the international field trial a report from the WHOQOL group. Khluwer Academic Journal, 3, 299-310. 